\title{
Impacts Of The National Economic And Social Development Plan On Songkhla Lake Basin Development Thailand
}

\author{
Narit Doungsuwan, Prince of Songkla University, Thailand \\ Chatchai Ratanachai, Prince of Songkla University, Thailand \\ Penjai Somgpongchaiyakul, Chulalongkorn University, Thailand \\ Prapaporn Sangganjanavanich, Prince of Songkla University, Thailand
}

\begin{abstract}
The objectives of this study were to explore the impacts of Thailand's eleven National Economic and Social Development Plans (NESDP or $N P^{l}$ ) on the development, natural resources, and environment of the Songkhla Lake Basin (SLB), Thailand, and to propose policy recommendations for this development. Data on development in the SLB were collected through literature reviews and through four focus group discussions for related stakeholders in the four sub-basins. Our results showed that the focus of development changed from economic development in NPI through NP7 to a new model of holistic "people-centered development" with an emphasis on sustainability in NP8 through NP11. During this time (1961-2013), economic development has progressed in the $S L B$. For instance, 443 irrigation projects were developed to support expanded rice paddy fields, the area of shrimp farms increased to a current total of 60,174 rais, rubber plantations encroached into $30 \%$ of the total watershed area, and the number of factories increased to 2,748. This increased development has led to water pollution, sedimentation in Songkhla Lake, degradation of the watershed, and the depletion of fishery resources, requiring urgent remedial action. We recommend that mechanisms are provided for the public to fully participate in formulating basin development plans by, for example, establishing a Songkhla Lake Basin Development Institute and conducting a basin-level strategic environmental assessment.
\end{abstract}

Keywords: National Economic and Social Development Plan; Songkhla Lake River Basin; Impacts of development

\section{INTRODUCTION}

The Songkhla Lake Basin (SLB) is located along the eastern coast of southern Thailand (see Figure 1) and is one of 25 river basins in the country. The basin has an area of $8,729 \mathrm{~km}^{2}$, including $7,687 \mathrm{~km}^{2}$ of land area and $1,042 \mathrm{~km}^{2}$ of lakes (ONEP, 2005). Sonkhla Lake is a lagoon lake with a salinity that varies seasonally, and the lake consists of four parts, including (1) a freshwater portion called Thale Noi in the upper region, (2) the Upper Songkhla Lake, (3) the Middle Songkhla Lake, and (4) the Lower Songkhla Lake connected to the Gulf of Thailand in the Muang district, Songkhla province (Sirichai \& Doungsuwan, 2009). The total population in the SLB was approximately 1.7 million people in 2011 (DPA, 2012) and the economy was dependent on the agricultural, industrial, wholesale/retail, and service sectors. In addition, the average per capita income has increased through time. For example, the average per capita income in Songkhla and Phattalung provinces in 2010 was 119,041 and $65,756 \mathrm{baht} /$ year, respectively, displaying an increase of 33\% and 54\%, respectively, from 2000 levels (NSO, 2012).

Thailand has formulated 11 National Economic and Social Development Plans (NPs) during the past 50 years. The first NP (NP1) through the fourth NP (NP4) were implemented between 1961 and 1981 and focused on economic development; NP5 through NP7 were implemented from 1982 to 1996 and focused on decentralizing

${ }^{1}$ It is customary to abbreviate National Economic and Social Development Plan as NP with the first plan denoted NP1, the second plan denoted NP2, and so forth. 
development; and NP8 through NP11 focused on people-centered development (Nopakun, 2010). During the first to seven NPs, it has been reported that the country experienced economic prosperity while facing numerous social problems, leading to unsustainable development (ONESDB, 2008).

Although the direction of development has changed since NP8, development under these plans continues to impact the SLB in negative ways. The objectives of this research were (1) to understand the impacts of Thailand's NPs on natural resources and patterns of development in the SLB and (2) to provide policy recommendations to resolve short- and long-term issues related to development in this region.

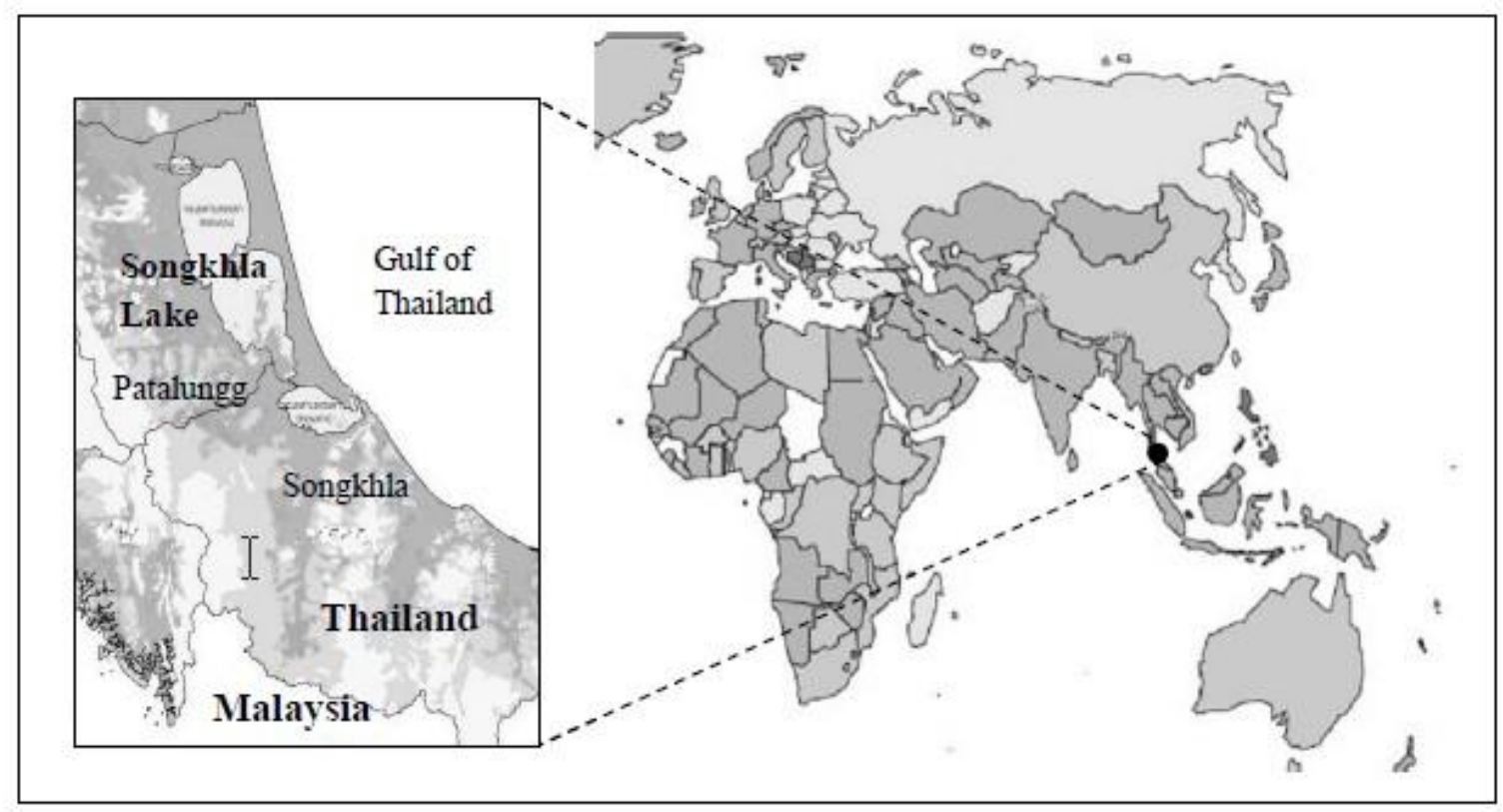

Figure 1: Location Of Songkhla Lake Basin

\section{METHODOLOGY}

We examined patterns of development and their impacts on natural resources and the environment in the SLB under the implementation of the 11 NPs from 1961 to 2013 following a literature review. The "Songkhla Lake Basin, Basins and Lakes impacts of Development: Irrigation, Aquaculture, Rubber plantation and Port" were search terms we looked for in the literature search, and collected only about 20 peer-reviewed, relevant articles. We also conducted four focus groups composed of representatives from related sectors, including the general public (89 persons), members of local administrative and government organizations (35persons), and individuals from academic institutions (18 persons), to discuss how past and present development have affected the SLB, and which specific questions were asked of them - "What is the problem of SLB, how would you describe the cause, and what is your opinion to solve the problem.?"

\section{RESULTS AND DISCUSSION}

\section{Literature Review: Pattern Of development In The SLB From 1961 To 2013}

Patterns of development in the SLB under Thailand's 11 NPs are summarized in Table 1.

\section{Development That Enhanced Agriculture And Aquaculture Productivity}

$\underline{\text { Irrigation Development For Rice Paddies }}$

NP2 was implemented from 1967 to 1971 with an objective of "Accelerating rice productivity through improving efficiency in production to increase productivity per rais" (ONESDB, 2008). Since 1948, 443 irrigation 
projects were initiated in the basin in order to expand rice field areas. Presently, there are 1,150,400 rais of rice fields that benefit from these irrigation projects. Moreover, five canals that connected the upper Songkhla Lake to the Gulf of Thailand were blocked in order to protect seawater intrusion (Sirichai \& Doungsuwan, 2009).

\section{Shrimp Aquaculture}

Since 1987, the area of the SLB comprised of rice fields have encroached by shrimp ponds with promotion of shrimp aquaculture under NP4 to NP 7 (1982-1996). Accordingly, tiger prawn (Peneaus monodon) aquaculture has rapidly expanded in the area around Songkhla Lake (Tanavud et al., 2001). Shrimp farms, in general, increased from 21,800 rais in 1982 to 48,700 rais in 2000 to 60,174 rais in 2011 (IRCNE, 2010), leading to a $276 \%$ increase in the area of shrimp farms from 1982 to 2011.

\section{$\underline{\text { Rubber Plantations }}$}

From1982 to1984, the Thai government gave farmers the right to convert forests to rubber plantations and offered them certificates of ownership (Tongrak, 2003). Accordingly, the area of the SLB comprised of rubber plantations increased following this policy and other guidelines for land reform under NP4 and for poverty alleviation under NP5 (DPA, 2012). Currently, rubber plantations continue to expand in the SBL and throughout Thailand because of increasing prices and demand for rubber, especially in neighboring China (RRIT, 2012).

Industrial And Infrastructure Development

Industry

NP1 through NP4 emphasized growth in the industrial sectors for export, leading to a steady increase in the growth of this sector (Pintobtang et al., 2002). The number of factories in Thailand grew from 2,431 in 2007 to 2,748 in 2011, with 2,276 of them as of 2011 located along highways in Songkhla province (Songkhla Province Industry Office, 2012).

\section{$\underline{\text { Songkhla Port }}$}

The Songkhla port was constructed following industrial development under NP1 through NP4 in order to increase economic efficiency within the SLB. This port was first proposed in 1982 (Talor et al., 1985) and became fully operable in 1987. Nine hundred and forty meters of rock-filled dam were also built at the southern portion at the mouth of Songkhla Lake (Kriengkajon, 2006). The direction of Thailand's NPs and pattern of development in SLB is shown in Table 1. 
Table 1: Direction of Thailand's NPs and Pattern of Development in SLB

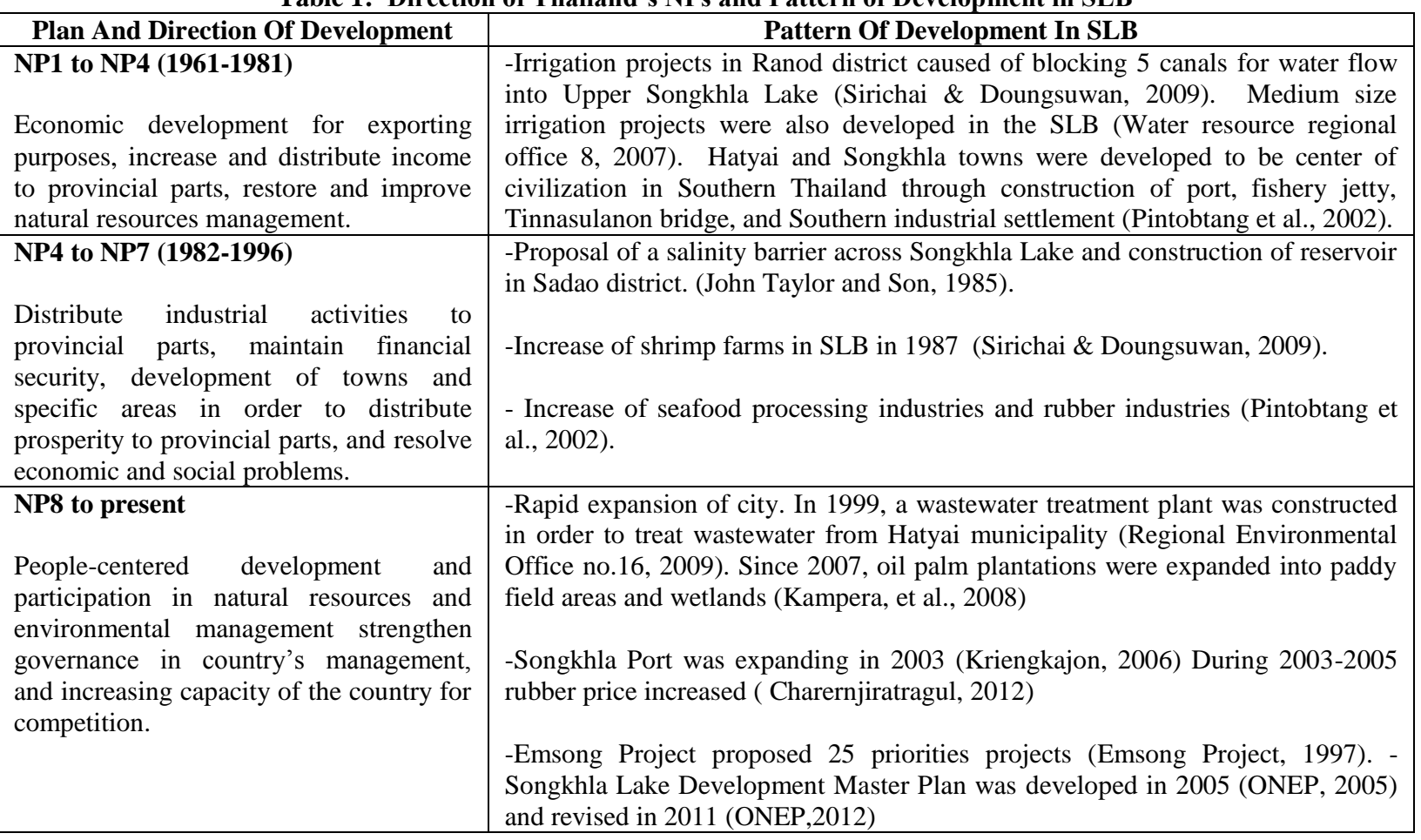

Focus Groups: Impacts Of Development On The Environment, Natural Resources, And Livelihoods Of Local People In The SLB

According to the results of the focus groups, participants cited a variety of problems related to development in the SLB (see Table 2), including barriers to water flow in Songkhla Lake, sedimentation in Thale Noi and Kukud, poor water quality caused by wastewater release, increases in agricultural, shrimp farm, and industrial areas, encroachment of peat swamp forest, land use conversion from rice paddies to rubber plantations, increasing coastal erosion around the outer part of Songkhla Lake, encroachment into the watershed for rubber plantations that has led to conflicts between local communities and government organizations, intrusion into protected areas, decreases in fishery resources due to overfishing, sedimentation of Songkhla Lake, and illegal fishery operations.

Table 2: Environmental Problems During Implementation Of Each NP That Identified By Stakeholders Of Focus Group Discussion In Four Areas

\begin{tabular}{|c|c|c|c|}
\hline Environmental Problems & $\begin{array}{c}\text { NP1-NP4 } \\
(1961-1981)\end{array}$ & $\begin{array}{c}\text { NP5-NP7 } \\
(1982-1996)\end{array}$ & $\begin{array}{c}\text { NP8-NP11 } \\
\text { (1997- Present) }\end{array}$ \\
\hline $\begin{array}{l}\text { - Blocking of flow in Songkhla Lake } \\
\text { - Sedimentation in Thale Noi and Kukud } \\
\text { - Poor water quality cause by wastewater released from communities } \\
\text { - Increase of agriculture area, shrimp farms and industries } \\
\text { - Encroachment of peat swamp forest } \\
\text { - Change of land use from paddy field to rubber plantation } \\
\text { - Increase of coastal erosion around outer part of Songkhla Lake } \\
\text { - Encroachment of watershed for rubber plantation purpose that lead to } \\
\text { conflict between local communities and government organizations, } \\
\text { interlope of protected areas } \\
\text { - Decrease of fishery resources because of over fishing, sedimentation } \\
\text { of Songkhla Lake, and illegal fisheries. }\end{array}$ & $\begin{array}{l}\checkmark \\
\checkmark\end{array}$ & $\begin{array}{l}\checkmark \\
\checkmark \\
\checkmark\end{array}$ & $\begin{array}{l}\checkmark \\
\checkmark \\
\checkmark \\
\checkmark \\
\checkmark \\
\checkmark \\
\\
\checkmark \\
\end{array}$ \\
\hline
\end{tabular}


Water flows have been blocked between Songkhla Lake and the Gulf of Thailand because of a watergate constructed at the confluence of these water bodies. This has further resulted in sedimentation and decreased water levels in Songkhla Lake (Kriengkajon, 2006). Similar patterns and consequences have been observed in saline waters in St. Lucia and the Mfolocy Rivers in South Africa, which have impacted the lake's longevity (Lawrie \& Stretch, 2011) and following the construction of a dam in the upper portion of the Lancan River in Yunan province, China, which has reduced water flow in the middle and lower portions of the river (Zhao et al., 2012). Conversely, when a new river mouth was constructed to connect Chilika Lake to the Bay of Bengal in India, improved water flow, lower sedimentation, and increased fishery resources and plankton production were observed (Chilika Development Authority, 2012; Dube et al., 2010).

In addition to decreased water flow, development in the SLB - specifically the expansion of shrimp aquaculture - has resulted in poor water quality and related environmental problems that have decreased the area's productivity. Similar issues have been observed in Bangladesh where shrimp aquaculture negatively impacted mangrove forests, other agricultural areas, water quality, salt water intrusion, and the abundance and diversity of aquatic species (Paul \& Vogl, 2011). Shrimp aquaculture has also led to eutrophication in New Caledonia Lake in southeastern Vietnam (Anh et al., 2010; Thomas et al., 2010) and severe saltwater intrusion (60\%) in coastal areas of Mexico (Berlanga-Robles et al., 2011).

Rubber plantations have encroached into many areas of the SLB, including Kao Pu- Kao Ya National Park. Currently, 30\% (90,000 rais) of a first class watershed in the U-tapao Sub-Basin has been converted to rubber plantations (Charernjiratragul, 2012). This activity has increased soil erosion and sedimentation in Songkhla Lake (Department of Mineral Resources, 2008). In the Changhua River Basin located in Hainan, China, rapid deforestation of more than $277 \mathrm{~km}^{2}$ has occurred for rubber and orchard plantations from 1995 to 2005 (Zhai et al., 2012), leading to soil deterioration through decreased organic matter and increased soil acidity (Zhang, 2007). In southeastern Vietnam, rubber plantations now occur on all land suitable for this activity (146,000 ha; Nguyen, 2012).

Fishery resources in Songkhla Lake have also deteriorated following changes to water flow, water quality, salinity, and sedimentation, which have impacted the livelihoods of local fishermen (Iwasaki \& Shaw, 2010). Moreover, overfishing in Songkhla Lake has led to declining fishery resources (Chesoh \& Lim, 2008); catch per unit effort (CPUE) of set bag nets in Songkhla Lake has decreased from $3.6 \mathrm{~kg} / \mathrm{set}$ bag net/day in 1994 (Choonhapran, 1996) to $0.77 \mathrm{~kg} / \mathrm{set}$ bag net/day in 2008 (Marine Resources Research Center and the Lower Gulf of Thailand Coast, 2008).

Finally, individuals in local communities have changed their occupations from farmers to other jobs (e.g., industrial labor). Labor jobs increased from 53,900 in 1997 to 78,000 in 2007 in Songkhla province (The Office of Industrial Economics, 2008) and from 409 in 1991 to 4,010 in 2009 in Phattalung province (PIO, 2011). As individuals began working outside of the community, social problems became more prevalent, including deteriorated relationships between community members, insufficient incomes, and increases in health problems and broken families (Peangnu \& Paduka, 2007).

\section{Recommendations For Future Development In The SLB}

Based on the literature review and discussions following the four focus groups, we make the following recommendations for future development in the SLB:

1. Emphasize the importance and urgency of current environmental and social problems. Current environmental issues, such as overfishing in Songkhla Lake, conversion of watersheds and peat swamp forests, water pollution, and coastal erosion, should be prioritized and addressed.

2. Integrate related development plans in the SLB. Several government organizations working in the SLB continue to work within their own isolated frameworks, leading to fragmented management within the region. A single development plan should be created that integrates the objectives and actions of all related institutions in the region. 
3. Promote participation in the public and related sectors. All stakeholders should be given the opportunity to be involved in the development of the region, from plan development to monitoring and assessment, in order to mitigate conflicts between stakeholder groups.

4. Perform a strategic environmental assessment (SEA). A SEA could act as an important tool for promoting the involvement of all sectors in determining initial concepts, developing more integrated plans in the future, and selecting appropriate policies, plans, and projects for sustainable development in the SLB.

5. Improve governance for the effective management of the SLB. Participation by government organizations, public sectors, and communities can promote social unity with the SLB for future generations.

\section{CONCLUSIONS}

Although Thailand's 11 NPs have led to critical socioeconomic advances in the region, they have also resulted in negative environmental impacts. For example, we found that over the last 50 years, development projects under the NPs have resulted in 1) water pollution caused by wastewater from agricultural and industrial activities, 2) increased sedimentation in Songkhla Lake resulting from soil erosion following landcover conversion, the blocking of water flows, and fishing activities, and 3) decreases in fishery resources that have resulted from the blocking and changing of water flows, the release of untreated wastewater from several sources, and the high use of legal and illegal fishing equipment.

Based on these results, we make a number of recommendations for resolving these environmental problems. Environmental threats should be prioritized and addressed immediately through, for example, regulations on fishing equipment and illegal fishing and the use of defensive measures to reduce landuse conversion. To achieve sustainable development in the SLB, effective basin management mechanisms and budgets should be integrated for all stakeholders through strategic environmental assessment tools. SEA will be an important tool to involve all sectors to determine sustainable development direction, participation of integrated plan and projects that correspond to the basin area to reduce confliction in the area, such as a case blocking of saline water Pak $\mathrm{Ra}-\mathrm{Wa}$, the saline barrier deep sea port, the reservoir project in the upstream area, to establish industrial estate, etc., as well as reducing the impact of SLB in the long-term.

\section{AUTHOR INFORMATION}

Mr. Narit Doungsuwan is a Ph.D. candidate, Faculty of Environmental Management, Prince of Songkla University, Hat Yai, Songkhla, Thailand. $\mathrm{He}$ is a lake and basin management specialist. E-mail: mailnarit@gmail.com (Corresponding author)

Dr. Chatchai Ratanachai is an associative professor, Faculty of Environmental Management, Prince of Songkla University, Hat Yai, Songkhla, Thailand. He is an environmental engineer and public policy specialist. E-mail: chatchai.ratanachai@gmail.com

Ms. Prapaporn Sangganjanavanich is a lecturer, Faculty of Environmental Management, Prince of Songkla University, Hat Yai, Songkhla, Thailand. She is an environmental lawyer. E-mail: prapaporn.s@psu.ac.th

Dr. Penjai Somgpongchaiyakul is an assistant professor at the Department of Marine Science, Faculty of Science, Chulalongkorn University, Bangkok, Thailand. She is a marine scientist. E-mail: penjai.s@chula.ac.th

\section{REFERENCES}

1. Anh, P., Kroeze, C., Bush, R., \& Mol, P.J. (2010). Water pollution by intensive brackish shrimp farming in south-east Vietnam: Causes and options for control. Agricultural Water Management, 34(6), 872-882.

2. Berlanga-Robles, C., Ruiz-Luna, Bocco, A., \& G. Vekerdy, Z. (2011). Spatial analysis of the impact of shrimp culture on the coastal wetlands on the Northern coast of Sinaloa, Mexico. Ocean \& Coastal Management, 54(7), 535-543. 
3. Charernjiratragul, S. (2012). Expanded rubber cultivation area concern and suggestions for policy. The report resources policy, agriculture and food security. Bangkok: National Health Foundation and Thai Health Promotion Foundation.

4. Chesoh, S., \& Lim, A. (2008). Forecasting fish catches in Songkhla Lake basin. Science Asia, 34(34), 335340.

5. Chilika Development Authority. (2012). Chilika Eco-Restoration. Retrieved on 10 November 2012 from, http://www.chilika.com/eco restoration.htm

6. Choonhapran, A. (1996). Study on fisheries resources and population changes in Songkhla Lake: Case study on 3 fishing gears. Technical paper 18/1996, National Institute of Coastal Aquaculture (NICA), Songkhla, Thailand.

7. Department of Mineral Resources. (2008). Project Management Resources, Songkhla Lake Basin. Geochemical survey and soil erosion in Lower Songkla lake Basin.

8. Department of Provincial Administration. (2012). Report statistic of population and houses in Thailand, December 2011. Retrieved on 20 August 2012 from, http://stat.dopa.go.th/xstat/pop54_1.html

9. Dube, A., Jayaraman, G., \& Rani, R., (2010). Coastal lagoons and their evolution: A hydromorphological perspective Estuarine, Coastal and Shelf Science, 4(3), 199-209.

10. Emsong Project. (1997). Environmental Management in Songkhla Lake Basin. Background and Justification Report No. 3/3 Environmental Action Programme. VKI in association with: DHI, PEM consult A/S, COWI A/S, Prince of Songkla University and Seatec International Ltd.

11. Informatics Research Center of Natural Resource and Environment. (2010). Natural resources profile Songkhla Lake Basin. Environmental Management Faculty Prince of Songkhla University Thailand.

12. Iwasaki, S., \& Shaw, R. (2010). Integrated Lagoon Fisheries Management: Resource Dynamics and Adaptation Community, Environment and Disaster Risk Management Volume 3 Emerald Books pp.1-218.

13. John Taylor and Son. (1985). Songkhla Lake Basin Planning Study Final Report Vol.1-9. (Main Report). Nation Economic and Social Development Board, National Environmental Board, Thailand.

14. Kampera, A., Yongsatitsak, T., Tongyoi, R., Yongchalermchai, P., Bennui, A., \& Rungtawanreungsri, S. (2008). Report Applications of SPOT-5 Satellite Images to Study the Landuse Changes from Paddy Fields into Other Cash Crops Plantations and Economic Valuation in Phattalung Province. Environmental Management Faculty Prince of Songkhla University, Thailand.

15. Kriengkajon, A. (2006) From deep sea port to fisherman around Songkhla Lake. Bangkok: Local Development Institute.

16. Lawrie, A. \& Stretch, D. (2011). Anthropogenic impacts on the water and salt budgets of St Lucia estuarine lake in South Africa Estuarine, Coastal and Shelf Science, 95(1), 67-76.

17. Marine Resources Research Center and the Lower Gulf of Thailand coast. (2008). The report of the operation work of the Department of fisheries in fiscal year 2008. Department of Marine and Coastal Resoucres, Misnistry of Natural Resources and Environment Thailand.

18. Nopakun, T. (2010). Concept and evolution to the country development planning. Economic and social journal, 47(2), 37-40.

19. National Statistical Office. (2012). Report of per capita income of population by region and province: 2000 - 2010. Retrieved on 10 January 2012 from, http://www.nso.go.th/ nso/E111114-43-53.xls

20. Nguyen, T. (2012). Large-scale altitudinal gradient of natural rubber production in Vietnam. Industrial Crops and Products, 41, 31- 40.

21. Office of Natural Resources and Environmental Policy and Planning. (2012). The review and amendment of the 2006-2015 master plan of the Songkhla Lake basin development (Final Report). Misnistry of Natural Resources and Environment.

22. Office of Natural Resources and Environmental Policy and Planning. (2005). Final Report: Songkla lake development project No.4 Forest- Fishery-Land use-Energy. Bangkok: Misnistry of Natural Resources and Environment.

23 Office of the National Economic and Social Development Board. (2008). National Economic and Social Development Plan The first-eleventh plan. Retrieved on 5 February 2012 from, http://www.nesdb.go.th/Default.aspx?tabid=427

24. Patalung province industry office. (2011)._An overview of industrial investment phatthalung 2009-2010. Retrieved on 30 September 2012 from, http://www.industry.go.th/ops/pio/phatthalung/Lists/annuity/Attachments/26pdf 
25. Paul, B. \& Vogl, C. (2011). Impacts of shrimp farming in Bangladesh: Challenges and alternatives. Ocean \& Coastal Management, 54(3), 201-211.

26. Peangnu, B., \& Paduka, A. (2007). Women and Songkhla Lake fishery resource management. Southern coastal natural resource management Project, Songkhla, Thailand.

27 Pintobtang P.,Kiyunwong, S., \& Boonchai, K. (2002). The state development policy to violate human rights rural community case: Songkhla Lake basin. Bankok : The Thailand Research Fund (TRF).

28. Regional Environmental Office no.16. (2009). Management of the Environmental quality in South east coast. Office of the Secretary of Misnistry of Natural Resources and Environment.

29. Rubber Research Institute of Thailand. (2012). Statistic of World rubber 1988-2011. Retrieved on 5 January 2012 from, http://www.songkhlarubber.com/index2.php?option=com wrapper\&viewwrapper\&Itemid=56

30. Sirichai, L.,Doungsuwan, N. (2009). The Development in The usage of resource in Songkhla Lake : A Study of Fisherfolk Community (Final Report). Bangkok : The Thailand Research Fund (TRF).

31. Songkhla province industry office. (2012). Industrial economic situation Songkhla 2007. Retrieved on 30 September 2012 from, www.industry.go.th/DocLib13/South/Songkhla.doc

32. Tanavud, C., Yongchalermchai, C.,Bennui, A.,Pensrisereekul, O. (2001). The Expansion of Inland Shrimp Farming and Its Environmental Impacts in Songkla Lake Basin. Kasetsart J. (Nat. Sci.), 35(3), 326 - 343

33. The office of industrial economics. (2008). Report economics industrial situation 1984-2007. Bangkok: Misnistry of Industry.

34. Thomas, Y., Courties, C., El Helwe, Y., Herbland, A., \& Lemonnier. H. (2010). Spatial and temporal extension of eutrophication associated with shrimp farm wastewater discharges in the New Caledonia lagoon. Marine Pollution Bulletin, 61(7-12), 387-398.

35. Tongrak, S. (2003). Evolution of land uses and forest land uses in Songkhla Lake Basin(Report). Bankok: The Thailand Research Fund (TRF).

36. Water resource regional office 8. 2007. Songkhla Lake basin water resources development Project. Retrieved on 15 January 2011 from, http://www.sbasin.net/index.php/

37. Zhai, Cannon, H., Slik, F., Zhang \& Dai. (2012). Rubber and pulp plantations represent a double threat to Hainan's natural tropical forests. Journal of Environmental Management, 96(1), 64-73.

38 Zhang, H., Zhang, Zhao Yu-Guo, Zhao Wen-Jun, \& Qi Zhi-Ping. (2007). Chemical degradation of a Ferralsol (Oxisol) under intensive rubber (Hevea brasiliensis) farming in tropical China. Soil \& Tillage Research, 93(1), 109-116.

39 Zhao, Q., Liu, S., Deng, L., Dong, S., Cong, Wang, Yang, Z., \& Yang, J. (2012). Landscape change and hydrologic alteration associated with dam construction. International Journal of Applied Earth Observation and Geo information, 16, 17-26. 